This article is (c) Emerald Group Publishing and permission has been granted for this version to appear here (http://epress.lib.uts.edu.au/research/handle/10453/9897). Emerald does not grant permission for this article to be further copied/distributed or hosted elsewhere without the express permission from Emerald Group Publishing Limited.' 


\title{
Integrating Blended Teaching \& Learning to Enhance Graduate Attributes
}

\begin{abstract}
Purpose - This paper explores the role of computer based business simulations in higher education as innovative tools of teaching and learning to enhance students' practical understanding of real business problems. Whether the integration of business simulation technologies will enable significant innovation in teaching and learning and will significantly enhance the quality and efficiency of traditional management teaching and learning methods is examined.
\end{abstract}

Antoine HERMENS

University of Technology Sydney

Sydney, Australia

Elizabeth CLARKE

University of Technology Sydney

Sydney, Australia

Approach - Previous research has established that simulations can be an effective integrative learning mechanism for the student participant seeking to understand management concepts, techniques and practices. A number of prominent training institutions have adopted simulations in order to increase business acumen, financial literacy and build competency.

Findings- The research carried out seems to confirm that simulations can be powerful, engaging, dynamic and effective teaching and learning tools. The immersive worlds of simulations can be designed to replicate actual economic, market and business events where students experiment in real time with alignment and commitment surrounding complex corporate strategies, business models and initiatives.

Originality- To achieve the required convergence of the business curriculum, we hypothesize that a broad-based integrative approach needs to be adopted to overcome the silo effect of supply driven disciplinary models which have traditionally prevailed in business education.

Keywords- Blended Learning, Business simulations, Graduate Attributes

Paper type- Applied research paper 


\section{INTRODUCTION}

The postgraduate business education market both nationally and internationally is defined by informed and focused students; the dynamics of this segment of the education market is shaped by an ever increasing number of providers from both the private and public institutions offering various business degrees and courses. Course content and design of courses are contextualized in a dynamic global business environment. Globalization has transformed contemporary business practice. Business education needs to come to terms with a developing global environment that has impacted on business demographics and culture which demands a change in managerial skills to lead sustainable enterprises. These changes have challenged educators to reassess course learning goals, outcomes and graduate attributes.

In the past decade course design tended to embrace an "in depth" knowledge methodology which examined specific subjects or functional disciplines or business models, arguably equipped students for a life-long career. The advent of the $21^{\text {st }}$ century heralded a new approach to course design and learning outcomes emphasizing the acquisition of broader generic management skills. Arguably these attributes equipped graduates with the necessary skills for movement between different business sectors and industries. Feedback from recent focus groups, and surveys conducted with senior business leaders, practitioners and alumni suggest that, there has been another shift. Essential skills for future high order leadership are listed as, problem solving skills. Managing flexible environments, utilizing technology effectively with the capacity for innovation in new market and technological contexts and are attributes highly valued.

To enhance the extent to which learning and teaching can transcend subject disciplinary approaches to develop an integrative analysis of complex business problems, utilizing technological support to achieve a total business perspective and to enhance staff understanding of these skills and how best to facilitate them in learning and teaching, also requires to achieve more consistency and integration in the use of case studies, business projects, simulations and other computer applications in each disciplinary field to build on existing student experiences and capabilities to achieve more robust graduate attributes. 


\section{TRADITIONAL VS INTEGRATIVE BLENDED TEACHING AND LEARNING}

Traditional methods of teaching and learning all have their strengths and limitations. Various authors recognize that traditional teaching methods lecture, textbook and case study on their own are not able to contribute towards the development of important high order management skills. For example:

Lecture/ Textbook: Under this format, students are usually "passive learners" , they are very efficient for communicating a large number of concepts to a large number of students, but it is doubtful their decision-making, creativity, integration of functional material, problem- solving, decision making, risk-taking, or interpersonal skills are improved by listening to lectures (Thorne et. Al, 1999:285), (Cadotte, 1995). Here are some of the examples:

Business ethics is the result of both personal and organizational influences, neither of which can be adequately experienced via passive learning neither will expose students to the myriad of viewpoints that can be taken on ethical issues. Thorne et. al (1999:285)

Strategic management is the result of integrating all the different functional and business decisions that can impact ROA, employee satisfaction, and customer satisfaction. What happens to ROA if I increase plant investments? Is there a correlation between employee satisfaction and customer satisfaction? What about between price changes, customer satisfaction, and earnings? Will the investment I am about to make be valued by the customer and differentiate me from my competition? How do income statement and balance sheet changes impact stock price?". Bolt (2005)

Case Analysis: At Harvard Business School for many years real business case-studies have provided the cornerstone of management education, integrating theory with applied business examples that provides the context in which students can gain in-depth knowledge. However, case-studies do have limitations as students are not able to see the consequences of their decisions and test alternative proposals, although considered by various authors as a major step in the transition from the academic to the business as it teaches 'problem solving' by allowing students to see the various personal factors and organisational circumstances that led to a specific situation and the importance of the issues presented, in this context students are considered 'active learners" as they read the case, analyse its issues and solve complex problems, thinking in strategic ways and make recommendations based on case facts, they learn from hindsight and the critique of their approaches from the instructor and class feedback. It has significant limitations on developing decision-making skills as "students do not have to exe- 
cute their decisions and live the consequences, nor opportunities to respond to competitive moves and countermoves or to deal with decisions of others", they tend to be narrowly focused and require little accountability on the student's part (Cadotte, 1995), (Thorne et. al 1999:285). Koeplin, (2003), reported that for teaching managerial accounting there are some inherent weaknesses in using a textbook, 'these weakness included piece-meal methodology where problems are not related or integrative; students having little or no opportunity to be decision makers; important relationships are not sufficiently recognized; the interaction between management and the management account is not experienced; the opportunity to prepare budge or profit plans based on the students own decisions does not exists; opportunities for creative and innovative approaches to learning are minimal; and also the traditional methodology does not allow students to experience the consequences of good or bad decisions'.

O’Hara , (2007:936), proposes that pedagogy will have to shift from knowledge to learning, as not only what we learn but how we learn it will need to change, "rapid information will result in rapid marginalization unless it comes in new ways of thinking about expertise, learning to learn becomes a core competence". Suggesting that, interactive pedagogies must be introduced into the learning context that is reflective not only with respect to particular content and individual self development, but also with regards to the group dynamics and human relations, to be effective in most areas of human activity understanding human relationships, group dynamics, leadership and unconscious dimensions of all these become core competence, and that, 'case based and problem embracing pedagogies should resolve real problems, as facts and theories in use on ground in real situations change faster than facts and theories about them in books and journals, and given the fact that many of the problems with which we must now must deal may have never been encountered before, education must become inquiry focused, problem embracing and case based with knowledge and learning derived from attempts to solve real problems'.

Business Simulation : The introduction of simulation technologies into current teaching methods provides a teaching tool to contextualise what is learned with lectures and case studies applying knowledge into real problems by learning by doing and enhancing understanding of cause and consequence. By complementing lectures with simulations, information from lectures can be used in games to deepen a person's understanding of them as, numerous con- 
cepts can be dealt with in one game, so that instead of just learning about one thing; the whole subject can be explored; In this way, participants can learn about the quality of their decisions directly and see how decisions can result on constraints on future decisions. The advantages of a model that allows different approaches, as in gaming, is that the game can be repeated or restarted with new ideas., whereas a case study can only really be used once. Gilgeous et al (1996).

With simulations, Romme (2002) states, the deep approach to learning goes beyond the given situation or problem and explores the larger issues represented by a particular problem, as opposed to the surface approach 'tied to what is given in the specific learning situation, e.g. text, problem or assignment, where the focus is on providing an answer in terms of the specific instance, and students adopting this approach are satisfied with memorizing isolated facts, concepts or ideas. In this context simulations are more likely to be more productive and valuable in deep than surface learning as the complex interplay of variables and forces in play challenge students to make sense of a certain complex problems in its wider setting and strategies that do not seem to work challenge students to explore changes in their mental maps and theories'

Learning in this context occurs on many levels; players learn from the contextual information contained in the dynamics of the game, the process of playing the game, through risk taking and weighing up the risks, benefits, costs, outcomes and reward resulting form decision making (Doyle, et.al., 2000) and as computerized simulations have the ability to compress time and space, it is possible to experiment and learn when the consequences of decisions and actions are in the future or in distant parts of the organization.

Cadotte (1995) proposes that an integration of lectures, case studies with simulation provides opportunities for enhancing the capabilities that each provide and demonstrates how the integration of simulation provides skills development according to emphasis, content and teaching method when using lectures/textbooks, case studies and business simulation, how by complementing each other, it enhances the learning experience that will equip students with more robust and relevant experiences. Table 1 below offers a comparison of skills development according to emphasis, content and method of learning when using lectures/textbooks, case studies or business simulation that demonstrate how the integrative approach comple- 
ment each other and how it enhances the learning experience that will equip students with more robust and relevant experiences and skills required for managers of the future.

Table 1 Developments of Skills According to Learning Approaches

\begin{tabular}{|c|c|c|c|}
\hline & Lectures/textbook & Case Studies & Business Simulations \\
\hline Emphasis & $\begin{array}{l}\text { Language } \\
\text { Tools of business }\end{array}$ & $\begin{array}{l}\text { Situation Analysis } \\
\text { Problem diagnosis } \\
\text { Problem Solving } \\
\text { Strategic Thinking }\end{array}$ & $\begin{array}{l}\text { Business Process } \\
\text { Execution of Strategy/Solutions } \\
\text { Management of tactics } \\
\text { Team work }\end{array}$ \\
\hline Content & $\begin{array}{l}\text { Concepts } \\
\text { Principles } \\
\text { Theory } \\
\text { Analytical tools }\end{array}$ & $\begin{array}{l}\text { Decisions situations: } \\
\text { 1. Diverse scenarios and con- } \\
\text { texts } \\
\text { 2. Complex problems }\end{array}$ & $\begin{array}{l}\text { Business processes interdepen- } \\
\text { dent decisions. Time phased im- } \\
\text { plementation continual adjust- } \\
\text { ment }\end{array}$ \\
\hline Method of Learning & $\begin{array}{l}\text { Knowledge Acquisition, } \\
\text { sequential presentation of } \\
\text { information } \\
\text { Cognitively passive } \\
\text { 1. Listening } \\
\text { 2. reading } \\
\text { 3. Memorization } \\
\text { Highly structured classroom } \\
\text { Low ambiguity } \\
\text { Right and Wrong deter- } \\
\text { mined by definition }\end{array}$ & $\begin{array}{l}\text { Critical Thinking } \\
\text { Sequential analysis of typi- } \\
\text { cal/important decisions } \\
\text { Cognitive active } \\
\text { Analysis } \\
\text { Debate } \\
\text { Semi structured classroom } \\
\text { circumscribed problems and } \\
\text { opportunities } \\
\text { High Ambiguity } \\
\text { Right and wrong determined } \\
\text { by logic }\end{array}$ & $\begin{array}{l}\text { Decision making and manage- } \\
\text { ment simultaneous treatment of } \\
\text { interdependent decisions } \\
\text { Cognitively and emotionally ac- } \\
\text { tive }\end{array}$ \\
\hline
\end{tabular}

Source: Abridged version of Caddotte (1995). Business Simulations: The next step in management training, Selections, Graduate Management Admission Council, Autumn Vol 8:19

\section{PEDAGOGICAL APPLICATIONS: LEARNING THEORY APPLIED IN SIMULATIONS}

\section{Experiential Learning}

Three types of learning occur through participation in a business simulation game being with use of technology or role plays that is categorized into cognitive, affective and skills resulting in experiential learning. Keys \& Wolfe (1990) The use of experiential exercises, games, and simulations actively engage learners in situations where they 'must act and observe the consequences of their actions' and since everyone taking part shares the same experiences 'learning 
occurs through dialogue among participants who share observations, feelings and thoughts and arrive together at conclusions about what has been learned' . (Kolb, et.al., 1984a). These four elements are the starting point of the process whereby knowledge is created through transformation of experience, as shown in Figure 1.

\section{Figure 1 Transformation Experience}

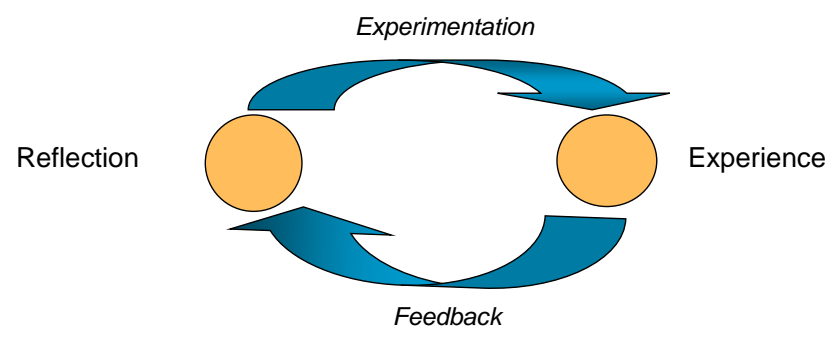

In order to bring about behavioural, attitudinal and knowledge change, (Keys et. al. 1989,) propose a four-state experiential learning model derived from Kolb's model, called the "Management of Learning Grid" based on the premise that an effective instructional style requires the balance of these factors: content, experience and feedback as being the essential factors to effective learning in simulations (Figure 2).

\section{Figure 2 Management of Learning Grid}

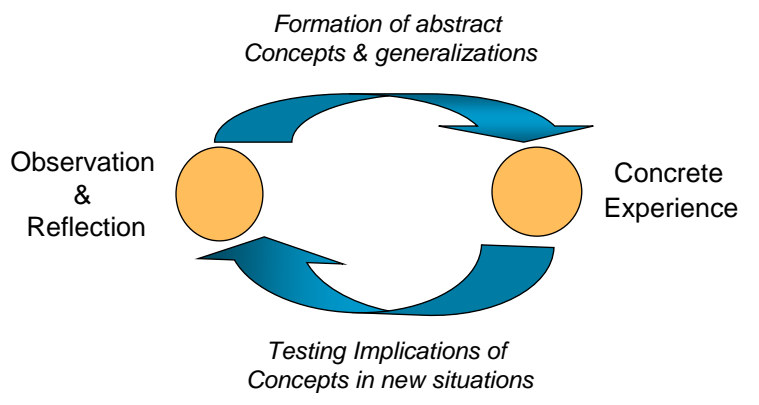

Where 'content' is defined as the dissemination of new ideas, principles, or concepts; 'experience' as an opportunity to apply content in an experiential environment; and 'Feedback' as to the result of actions taken and the relationship between performance at each chronological phase in experience and subsequent result. 'The Management of Learning Grid' has been used in the development of experiential environments (Butler and Keys, 1973), in the interpretation of simulation gaming research (Keys 1977), in the design of business games research 
(Keys and Bell, 1977) and as a typology for organizing management development research ( Keys and Wolfe 1990).

\section{Dynamic Thinking}

Dynamic content refers to system and cyclical aspects of learning that focuses on "learning to $d o^{\prime \prime}$ as opposed to traditional teaching methods lecture or books, which use passive learning content (linear content) that teaches on "learning to know', rather than "learning to do". Systems are the often invisible layer between what we do (Action) and what we get (Results). Cyclical content is a collection of actions as logical as notes of music or words in a sentence that are effective in contexts of activities (the action is the what, the activity is the why) to impact an environment and create an outcome. Adding these elements to the learning experience, further scope to the dimension of experiential learning, and forms the convergence point where dynamic and linear content "can be learnt simultaneously". Computers today can cost effectively cover these three types of content and when simulation, games and pedagogy elements are added to the dynamic and linear content they become the essential elements that are necessary for a successful educational experience'.

\section{Figure 3 Educational simulations happen at the convergence of the three essential} elements that are necessary for successful educational experiences

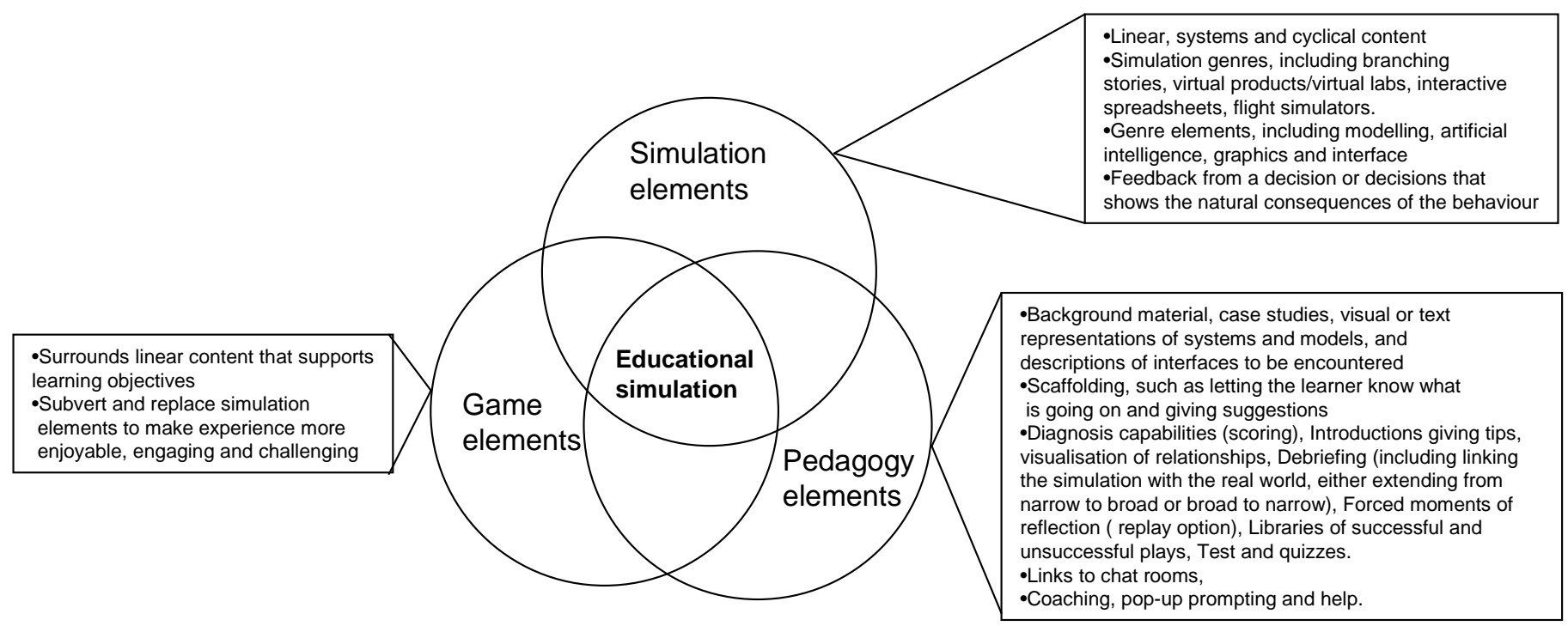

Source: Adapted from Aldrich 2004: 80-91 
Simulation elements selectively represent objects or situations, and selectively represent user interaction and enable discovery, experimentation, role modelling, practice and active construction of systems, cyclical and linear content that enable transferability to the real world (Figure 3). Game elements, provide familiar and entertaining interactions that increase the enjoyment derived from the educational experience and can be used to modify simulation elements after learners achieve certain levels of competency and encourage trying new approaches. Pedagogy elements, are learning objectives, the reasons to build the simulation and deciding what to simulate. Aldrich (2004:70)

\section{Systems Thinking}

Systems thinking, is an approach to problem solving that views "problems" as part of an overall system, rather than reacting to present outcomes or events and potentially contributing to further development of the undesired issue or problem (O'Connor and McDermott, 1997), a framework based on the belief that the component parts of a system can best be understood in the context of relationships with each other and with other systems, rather than in isolation, and proposes that the only way to fully understand why a problem or element occurs and persists is to understand the part in relation to the whole. (Capra,1996). This reflects how real business, go through certain processes to produce certain outputs, which together, accomplish the overall desired goal, as organizations are made up of many administrative and management functions, products, services, groups and individuals, where if one part of the system is changed, the nature of the overall system will also change (McNamara, 2002), which reflects a very important aspect of learning, as most critical decisions made in our organization have system wide consequences that stretch over years or decades such as decision on R\&D have first order consequences in marketing and manufacturing, decisions in investing in new manufacturing facilities and processes influences the quality and delivery reliability for a decade or more. (Senge 1995)

\section{Systems Dynamics}

System dynamics is an approach to understanding the behaviour of complex systems over time. It deals with internal feedback loops and time delays that affect the behaviour of the entire system (MIT Systems Dynamics), the feedback elements help to understand and describe how even seemingly simple systems display baffling nonlinearity explanations. 


\section{Problem Based Learning}

An instructional approach where students are confronted with a problem and challenged to work towards a solution, the learning experience imparts knowledge to be used rather than facts to be acquired. (Anneta et al 2007), helping learners to acquire and develop the knowledge, skills and capabilities needed to solve problems effectively (Engel. 1997). Problem based learning (PBL), is an approach for learning more in line with the fact that, practical problems are usually complex and ill-structured, that do not provide enough information for a simple resolution. The presentation of fragmented information, along with the learners' assumption of roles that provide a connection to the situation, motivates them through the problem-solving process, resulting in different types of problems which engage different cognitive processes and require different problem solving skills. (Anneta et al, 2007)(Kiili, 2007). The way PBL works is that it confronts students with a situation where they assume the role of a stakeholder and through investigation, learn whatever is necessary to arrive at a justifiable solution, as the task is authentic and their engagement with it is sustained, learners appreciate the utility of the knowledge they are learning and can recognize when this knowledge is applicable. Another element of PBL is that, learning is a social process, where cognitive change occurs as a result of interaction with others who may hold different understandings as they may challenge and refine a learner's current views and fulfils that by providing opportunities for learners to articulate new knowledge (Anneta et al., 2007).

This approach applied into simulations technology translates into the Problem Based Game Model (PBG), Kiili $(2005,2007)$, proposes that the PBG emphasizes the meaning of authentic learning tasks, experiential learning and collaboration, because games usually allow players to creatively test hypotheses and reflect on outcomes in the game world. As the authenticity of learning situations and tasks is assumed to be a very important factor in facilitating higher order learning in higher education, the basic idea is to anchor the learning knowledge and skills into meaningful problem solving situations as such an approach supports the transferability of learned knowledge and skills into practice.

\section{MEDIATING TECHNOLOGY THAT ACTS AS A TEACHING FRAMEWORK}

According to Arias Aranda (2007), from a teaching perspective, business simulations act as a 'mediating' technology that acts a teaching framework in the form of "game rules": In this way learning is achieved in two phases. First, participants have to decide which decisions fit better 
with their final goal, that is, to win the competition and become the virtual firm with the highest accumulated profit; second they have to consider how the decisions of the other participants are going to affect their own decisions; And reinforces learning through the feedback obtained when the decisions are processed and the results are made available to the participants. This process allows participants to modify and improve their decisions according to previous experience and it is demonstrated in Figure 4.

\section{Figure 4 Two-Fold process of Simulations in Teaching and Learning}

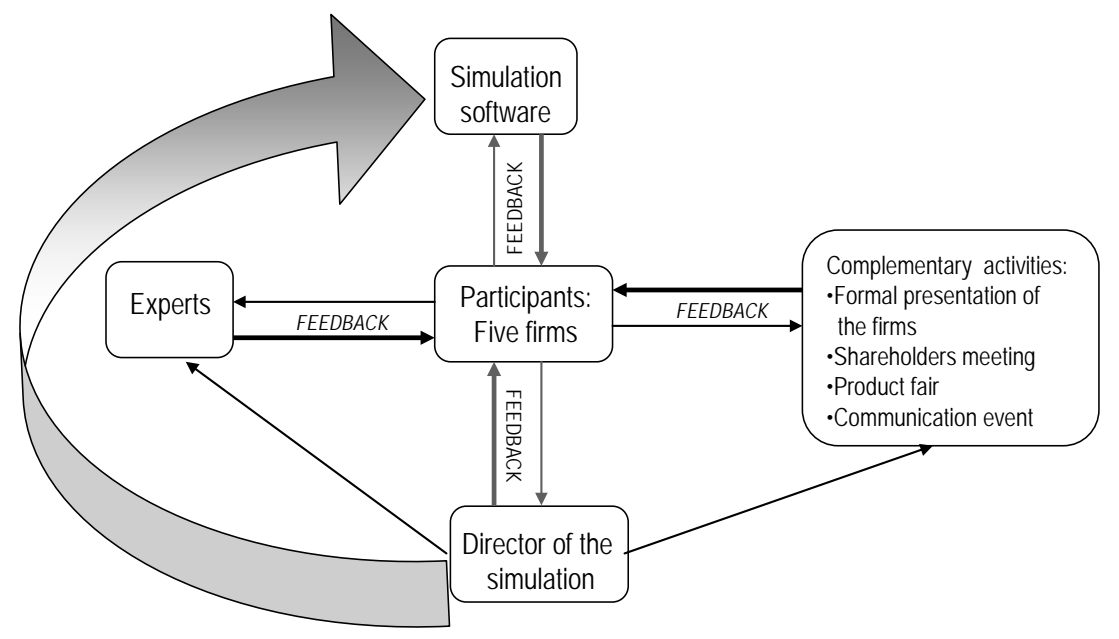

From a learning perspective, simulations provides opportunities for the development of high order thinking skills as per Bloom's taxonomy. Educational outcomes have adopted Boom's taxonomy of learning objectives to follow the thinking process and develop high order level thinking skills and by identifying the cognitive domain and the stages within them it distinguish more clearly a particular learning outcome being pursued as well as the degree to which the outcome has been accomplished. Students are not simply passive receivers of information or memorizing information but are actively involved in the creation of the process, and as a simulation react to the user's input and requires more than one than one interaction, they assist learners to develop critical thinking skills that might otherwise be difficult to acquire using traditional methods". (De Freitas, and Jarvis 2007), by experiencing real business complex situations simulations confront students with changes to the business and its environment over time-scales that match the firm's circumstances; and provide an opportunity to play out the theory in the context of developing business scenarios (Cadotte ,1995). Providing an environment that is experimental, experiential and rigorous that promotes creativity among the participants who develop a shared view of their learning (Gilgeous et.el 1996). Practicing 
business skills in this environment, offers the potential to develop high order managerial skills as students and their teams have the opportunity to work either as top managers or entrepreneurs, increase their business acumen and knowledge, understand to survey the market, identify and evaluate market opportunities, design and execute a business plan, monitor their own performance, and that of the competition and adjust their strategy and tactics as necessary (Cadotte, 1995; Romme, 2002; Anderson and Lawton, 2004).

Further, students develop cross functional decision making skills as business simulations in strategy particularly, aim at consolidating knowledge about the different aspects of running a company, they encourage the development of cross functional skills, as participants apply core business skills to problem analysis and decision making and learn to use information effectively Annetta, L., Cook, M., Schultz (2007). They become involved in analyzing the revenue-cost profit economics of a business, by helping to understand how the functional pieces of a business fit together it gives opportunities for the students to experience and practice assessing business risk, analyze industry and competition conditions, making decisions from a companywide perspective, thinking strategically about a company's market position and the kinds of actions it will take to improve it, developing strategies and revising them in light of changing conditions. (Anitsal, and Cadotte 2007; Arias-Aranda, 2007; Cameron, 2003).

\section{BRIDGING THE GAP}

Computer based business simulations are not meant to replace lectures but to support them, Gilgeous et al, (1996), states that information from lectures can be used in games to deepen a person's understanding of them as, "numerous concepts can be dealt with in one game, so that instead of just learning about one thing; the whole subject can be explored; this is far more interesting and promotes a larger scope of learning," and propose that business simulation games, as case studies, "can also represent a snapshot of a hypothetical company controlled by the designer, the model that is designed can be used to generate any outcome from any possible solution proposed. In this way, participants can learn about the quality of their decisions directly and see how decisions can result on constraints on future decisions". The advantages of a model that allows different approaches, as in gaming, is that the game can be repeated or restarted with new ideas., whereas a case study can only really be used once. 
The literature states that computer assisted simulation learning if implemented properly can be very advantageous. For example, computer facilitated activities to support learning lies not so much in the technology as in what teachers do with the available technologies (Onchwari and Onchwari, 2009), and can potentially change the role of the instructor from the main source of information and power to a partner/facilitator of learning.

But while implementing these technologies to enhance the tutorial aspects of an educational experience of which computer assisted learning is a part, ample opportunity must be afforded the student to interact with fellow students and explore learning in greater depth under the guidance of tutors and lecturers. Addressing these issues of 'going beyond' and 'interacting' is important if the potential of computer assisted learning for teaching and learning in higher education is to be fully realized above and beyond the mere enhancements in the quantity and quality of presentation of information. (Rainbow \& Sadler-Smith, 2003 ). Institution should clearly articulate its learning objectives and then place a high priority on including curriculum redesign in the planning process for new learning spaces. Faculty who are genuinely engaged in pedagogy, along with others who are concerned with the teaching and learning aspects of the space, should play a central, not peripheral, role in planning groups. (Lippincott, 2009) 


\section{Figure $5 \quad$ Levels and Skills Involved in Competing Business Simulations}

\author{
Business Acumen \\ WebMarketPlace, \\ Venture Strategy, \\ Strat-Sim Management \\ Country Manager \\ The Global Business Game, \\ The Business Policy, \\ The Business Game, The \\ Enterprise Game, \\ Harvard Business School Publishing \\ Strategic Innovation \&Technology Sim \\ Breakaway \\ TOPSIM General Management Sim \\ IBM Innov8, \\ CAPSIM, \\ BT Better Business game \\ L'oreale-STRAT 8 Challenge, \\ Airline Mogul \\ Airway Sim \\ The Glo-Bus, \\ The Business Strategy Game, \\ The Corporation,
}

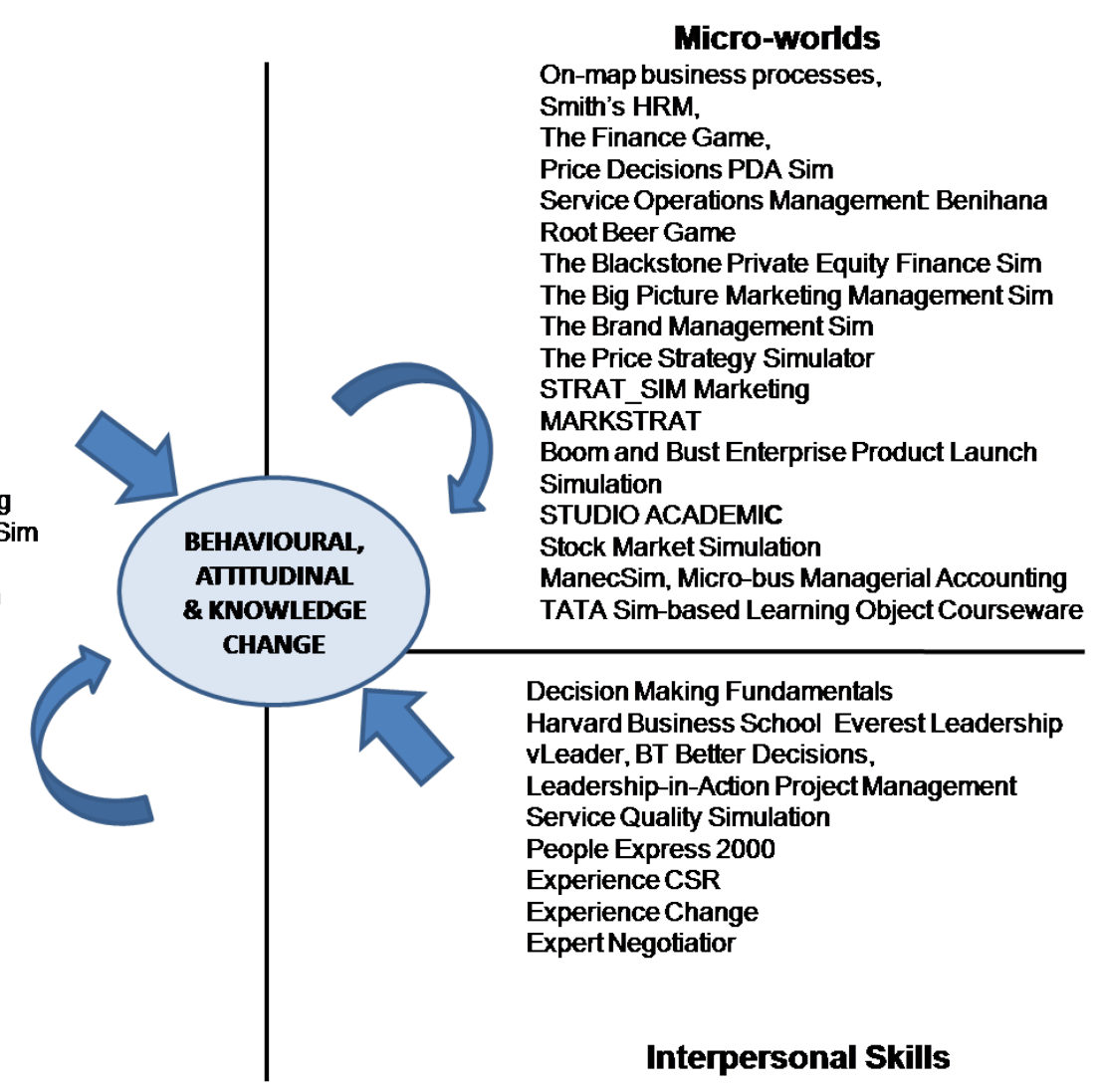

\section{Interpersonal Skills}

\section{Macro-worlds}

Anderson and Lawton (2009), noted that it is important to make a distinction between the goal of the goal of the simulation and the teaching learning goal, as there is plenty of evidence to suggest that, since performance should not be used as a proxy for learning, there is no relationship between game performance and learning , as in some cases students can be successful in the game while a learning test does not reveal an increase in knowledge (Summers, 2004), and because the student does not have to be successful in the simulation to learn.

There is a proliferating number of business simulations on the educational market, competing in terms of the levels and skills involved in the simulation. Some simulations are aimed at enhancing business decision making skills in a macro-economic global market environment. Other simulations are more based on interpersonal skill development in sectoral or microeconomic business contexts (Figure 5). 
There are now business simulations available across the disciplines of the curriculum, and others aimed at inter-disciplinary analysis. Selecting the right business simulation entails a consideration of the scope and complexity of the simulation, and whether the skills to be developed are functional or involve general management decision-making. The increasing array of business simulations offers some choice, and increasingly simulations offer a degree of customisation (Table 2). Further development of the responsiveness and relevance of business simulations will contribute to their wider use in delivering the business curriculum. 
Table 2 Comparison of Scope and Functionality of Competing Business Simulations

\begin{tabular}{|c|c|c|c|c|c|c|c|}
\hline $\begin{array}{c}\text { Learning } \\
\text { Goals }\end{array}$ & Discipline & Scope & Difficulty & Industry & \begin{tabular}{|c|} 
Functional vs \\
total enterprise
\end{tabular} & Interaction & Name of Simulation \\
\hline $\begin{array}{l}\text { Decision } \\
\text { making } \\
\text { Critical } \\
\text { thinking } \\
\text { Problem } \\
\text { solving } \\
\text { Innovation } \\
\text { \& creativity }\end{array}$ & $\begin{array}{l}\text { Business } \\
\text { CSR Busi- } \\
\text { ness }\end{array}$ & $\begin{array}{l}\text { Interpersonal skills } \\
\text { Stakeholders analy- } \\
\text { sis } \\
\text { Managing change }\end{array}$ & Complex & $\begin{array}{l}\text { Various } \\
\text { Innovation } \\
\text { across in- } \\
\text { dustries }\end{array}$ & Functional & $\begin{array}{l}\text { Single/ multi } \\
\text { player } \\
\text { CD license } \\
\text { Online multi- } \\
\text { player } \\
\text { Free of charge } \\
\text { By membership }\end{array}$ & $\begin{array}{l}\text { Decision Making Fundamentals \& } \\
\text { Experience CSR } \\
\text { (Experience Point) } \\
\text { BT The Better Business Game } \\
\text { (BT) } \\
\text { Expert Negotiator (Planning \& } \\
\text { management software) }\end{array}$ \\
\hline $\begin{array}{l}\text { Problem } \\
\text { solving, } \\
\text { Decision } \\
\text { making } \\
\text { Group dy- } \\
\text { namics } \\
\text { Motivation }\end{array}$ & Business & $\begin{array}{l}\text { Interpersonal skills } \\
\text { Applied leadership } \\
\text { Situational Aware- } \\
\text { ness, Active Listen- } \\
\text { ing and Effective } \\
\text { Communication, }\end{array}$ & Complex & & $\begin{array}{l}\text { Functional } \\
\text { IT Project man- } \\
\text { agement } \\
\text { Functional }\end{array}$ & $\begin{array}{l}\text { Multiplayer online } \\
\text { membership } \\
\text { Multiplayer CD } \\
\text { license }\end{array}$ & $\begin{array}{l}\text { Harvard Business School Everest } \\
\text { Leadership (Forio), VLeader } \\
\text { (SimuLearn), Leadership in Ac- } \\
\text { tion Project Management (Forio) } \\
\text { People Express } 2000 \text { (Strategy } \\
\text { Dynamics), Experience Change } \\
\text { (Experience Point) }\end{array}$ \\
\hline $\begin{array}{l}\text { Apply core } \\
\text { business } \\
\text { skills to } \\
\text { problem } \\
\text { analysis \& } \\
\text { decision } \\
\text { making. } \\
\text { Apply } \\
\text { cross- } \\
\text { functional }\end{array}$ & $\begin{array}{l}\text { Business } \\
\text { strategy }\end{array}$ & $\begin{array}{l}\text { Business acumen } \\
\text { formulating strat- } \\
\text { egy, allocate scarce } \\
\text { resources, develop } \\
\text { products and ser- } \\
\text { vices, meet cus- } \\
\text { tomer requirements, } \\
\text { manage financial } \\
\text { metrics, compete } \\
\text { against other man- }\end{array}$ & Complex & $\begin{array}{l}\text { Retail, Fi- } \\
\text { nancial } \\
\text { services, } \\
\text { Retail, } \\
\text { Manufac- } \\
\text { turing, } \\
\text { cosmetics }\end{array}$ & Total Enterprise & $\begin{array}{l}\text { Online multi- } \\
\text { player member- } \\
\text { ship }\end{array}$ & $\begin{array}{l}\text { Webmarket Place (Innovative } \\
\text { Learning), Venture Strategy, } \\
\text { Strat-Sim Management, The } \\
\text { Business Game (Pixel learning), } \\
\text { Country manager (Interpretative } \\
\text { Simulations), The Global Busi- } \\
\text { ness Game (Innovative Learning), } \\
\text { The Business Policy (Eskimo), } \\
\text { The Enterprise Game (Pixel } \\
\text { learning), HBS Strategic Innova- } \\
\text { tion \& Technology Simulation }\end{array}$ \\
\hline
\end{tabular}




\begin{tabular}{|c|c|c|c|c|c|c|}
\hline $\begin{array}{l}\text { skills and } \\
\text { use infor- } \\
\text { mation ef- } \\
\text { fectively }\end{array}$ & & $\begin{array}{l}\text { agers in a shifting } \\
\text { competitive land- } \\
\text { scape. }\end{array}$ & $\begin{array}{l}\text { Cosmetics } \\
\text { IT BPS } \\
\text { Airline }\end{array}$ & & $\begin{array}{l}\text { Online multi- } \\
\text { player } \\
\text { Free of charge }\end{array}$ & $\begin{array}{l}\text { (Forio), CAPSIM (Management } \\
\text { Simulations), Industry Player } \\
\text { (Tycoon Systems), TOPSIM gen- } \\
\text { eral management Simulation } \\
\text { (Tata), BT Better Business Game } \\
\text { (BT), The Glo-Bus Game ( Mc } \\
\text { Graw Hill), The Corporation } \\
\text { (Smith \& Golden). The Business } \\
\text { Strategy Game ( Mc Graw Hill). } \\
\text { L'oreal e-STRAT Challenge, } \\
\text { IBM INNOV8 } \\
\text { Airline Mogul (Murphy), Airway } \\
\text { Simulation (Avia Design Ky) }\end{array}$ \\
\hline & $\begin{array}{l}\text { Business } \\
\text { processes }\end{array}$ & $\begin{array}{l}\text { Business specific } \\
\text { functional skills, } \\
\text { Manage employee } \\
\text { Performance and } \\
\text { organizational } \\
\text { change in a dynamic } \\
\text { and volatile busi- } \\
\text { ness environment }\end{array}$ & $\begin{array}{l}\text { Finance } \\
\text { services, } \\
\text { marketing, } \\
\text { operations, } \\
\text { supply } \\
\text { chain, cus- } \\
\text { tomer ser- } \\
\text { vice, }\end{array}$ & Microworld & $\begin{array}{l}\text { Online multi- } \\
\text { player member- } \\
\text { ship }\end{array}$ & $\begin{array}{l}\text { On-map business processes } \\
\text { (Nomia), } \\
\text { The Finance Game (Pixel learn- } \\
\text { ing), From Forio Simulations: } \\
\text { Price decisions PDA Sim, Service } \\
\text { Operations management: Beni- } \\
\text { hana, The Root Beer Game, The } \\
\text { Black-stone Private Equity Fi- } \\
\text { nance Simulation, Innovation \& } \\
\text { Technology Strategy Simulation, } \\
\text { The Price Strategy Simulator, } \\
\text { Universal car rental, Boom and } \\
\text { Bust Enterprise product launch } \\
\text { simulation, The Big Picture Mar- } \\
\text { keting simulation, Service Qual- } \\
\text { ity, Brand Management, Price } \\
\text { Strategy. } \\
\text { Strat -Sim Marketing (Interpre- } \\
\text { tative Simulations), MarkSTRAT } \\
\text { (StratX), Studio Academic (Pow- } \\
\text { erSim), ManecSim (ADS BS), Sim- } \\
\text { based Learning Object (Tata). }\end{array}$ \\
\hline
\end{tabular}




\section{REFERENCES}

Aldrich, C. (2004). Simulations and the future of learning: An innovative (and perhaps revolutionary) approach to e-learning. San Francisco: Pfeiffer.

Anderson, P.H. and L. Lawton (2004) "Applying Problem Based Learning Pedagogy to a Simulation Exercise.” Proceedings of the Applied Business Research Conference. March, 2004.

Annetta, L., Cook, M., Schultz (2007). Video Games: A Vehicle for Problem-based Learning. e-journal of Instructional Science and Technology (e-JIST) Vol. 10, No. 1.

Anitsal, M. M. and E. R. Cadotte (2007). The Application Of Means-End Theory To Understanding The Value Of Simulation-Based Learning. Annual Conference of the Association of Business Simulations and Experiential Learning (ABSEL).

Arias-Aranda, D. (2007). "Simulating reality for teaching strategic management." Innovations in Education and Teaching International 44(3): 273-286.

Bolt, J. F. (2005). "The Future of Executive Development." Executive Development Associates, Inc

Butler, J.L. and Keys, B. (1973). A Comparative Study of Simulation and Traditional Methods of Supervisory Training in Human Resource . Academy of Management Proceedings, 33rd Annutal Meeting, 1973

Cadotte, E. R. (1995). "Business Simulations: The Next Step in Management Training." The Magazine of the Graduate Management Admission Council, Autumn.

Capra, F. (1996) The web of life: a new scientific understanding of living systems (1st Anchor Books ed). New York: Anchor Books. p. 30

Cameron, N. E. (2003). "Teaching Tools: Simulating Money Supply Creation in Class" Economic Inquiry: 686-693.

De Freitas, S. I. and Jarvis S. (2007). "Serious games engaging solutions: A research and development project for supporting training needs”. British Journal of Educational Technology Vol.38(3): 523525.

Doyle, D., and Brown W. (2000). Using a business simulation to teach applied skills - the benefits and the challenges of using student teams from multiple countries. Journal of European Industrial Training; 24(6): 330-336.

Engel, C. (1997). Not just a method but a way of learning. In David Boud and Graham E. Felleti, The Challenge of Problem Based Learning. Kogan Page.

Gilgeous, V. and D’Cruz, M., (1996). A Study of Business and Management games; Management Development Review. 9 (1): 32-39. MCB University Press · ISSN 0962-2519 
Kenworthy, J. and Wong A. (2005). Developing Managerial Effectiveness: Assessing and comparing the Impact of Development Programs using a management simulation or management game. Developments in Business Simulations and Experiential Learning, Volume 32.

Keys, B. and J. Wolfe (1990). "The Role of Management Games and Simulations in Education and Research." Journal of Management 16(2): 307.

Keys, B., and Wolfe, J. (1997). Business Simulations, Experiential Learning in International Business Education.

Keys, B., and Wolfe, J. (1989). The Management of Learning Grid for Management Development Revisited. Journal of Management Development; 8(2): 5-12

Keys, B. (1977). Review of Learning Research in Business Gaming. Computer Simulation and Learning Theory, Volume 3.

Keys, B., and Bell, (1977). A Comparative Evaluation of the Management of Learning Grid Applied to the Business Policy Learning Environment

Kiili, K. (2007). Foundation for problem-based gaming; British Journal of Educational Technology; 38(3): 394-404

Kiili, K. (2005). Digital game-based learning: Towards an experiential gaming model; The Internet and Higher Education, 8(1): 13-24. Elsevier Inc.

Koeplin, J. (2003). The Management Accounting Simulation : An Approach to Bringing Decision Making into an Introductory Managerial Accounting Course. Journal of the Academy of Business Education; Vol. 4, Proceedings 2003. abe.villanova.edu/proc2003/proceed2003.html

Kolb, D.A., I.M. Rubin, and J.M. McIntyre (1984a), Organizational Psychology: An experiential approach, Englewood Cliffs, NJ: Prentice-Hall.

Kolb, D. A. (1984b). Experiential learning: experience as the source of learning and development, Englewood Cliffs, NJ: Prentice-Hall.

Kolb, D. A., S. Lublin, et al. (1986). "Strategic Management development: Using experiential learning theory for assessment and development of managerial competencies." The Journal of Management Development 5(3): 13-24.

Kolb, D. A., I. M. Rubin, et al. (1991). The organizational behavior reader: An experiential approach, 68-78, Englewood Cliffs, NJ: Prentice Hall.

Lippincott, J. (2009). Learning Spaces: Involving Faculty to Improve Pedagogy, EDUCAUSE Review, 44 ( 2): 16-25, (March/April).

McNamara, C. (2002). Training and Development in Board Resources, Authenticity Consulting, LLC Minneapolis, US.

O'Connor, J. \& McDermott, I. (1997). The Art of Systems Thinking: Essential Skills for Creativity and Problem-Solving. San Francisco: Thorsons Publishing. p. 11.

O’Hara, M. (2007). 'Strangers in a strange land: Knowing, learning and education for the global knowledge society’. Futures 39 (2007) 930-941. Elsevier. 
Onchwari, G., \& Onchwari, J.and Keengwe, J. (2009). Technology and Student Learning: Toward a LearnerCentered Teaching Model; Association for the Advancement of Computing in Education Journal, 17 (1): 11-22. Chesapeake, VA: AACE

Rainbow, S.W. and Sadler-Smith E. (2003). Attitudes to Computer Assisted Learning Amongst Business and Management Students. British Journal of Educational Technology, 34( 5):615-624

Romme. A.G.L. (2002). Microworlds for Management Education and Learning. Tilburg University Faculty of Economics \& Business Administration. UNICE http://www.unice.fr/sg/resources/articles/romme_2002_microworlds-management-ed-learning.pdf

Senge, Peter. 1990. The Fifth Discipline: the Art and Practice of the Learning Organization. New York: Doubleday.

Summers, G. J. (2004). Today’s Business Simulation Industry. Simulation \& Gaming, 35 (2): 208-241; Sage Publications

Thorne, L. D., L. Ferrell, et al. (1999). "The Use of a Behavioral Simulation to Teach Business Ethics." Teaching Business Ethics 3(3): 283-296.

Tonks, D. and S. Armitage (1997). "A framework for understanding learning from management simulations." Journal of Computer Assisted Learning 13(1): 48-58. 